\section{Kusyj J., \\ Kuk A., Topilnytskyy V.}

\title{
VIBRATORY-CENTRIFUGAL STRENGTHENING'S INFLUENCE ON FAILURE-FREE PARAMETERS OF DRILLING PUMPS BUSHINGS
}

Проаналізовано причини відмов деталей бурового устаткування. Розроблено метод вібрачійно-відиентрового змічнення для забезпечення показників надійності деталей типу «втулка». Адаптовано вібромашину об'ємного оброблення для поверхневого вібращійно-відцентрового змічнення. Приведено принщипову схему вібромашини та технологічного оснащення для зміцнення втулок. Опращьовано та проаналізовано результати експериментальних досліджень і натурних випробувань.

Ключові слова: технологічне оснащення для змічнення втулок, буровий інструмент, циліндрова втулка, вібраційно-відиентрове змічнення.

\section{Introduction}

In modern engineering, the requirements for product reliability are increasing, due to the complexity of modern technology, increasing loads during the operation of systems and elements, the conditions of their operation, increasing requirements for the quality of products, partial or complete automation of production processes [1-4]. Reliability largely depends on the performance characteristics: wear resistance, fatigue strength, corrosion resistance, etc., as well as safety, economy, service life and product competitiveness $[1,5,6]$.

At the present stage of the development of mechanical engineering with the complication of structures, technologies for manufacturing and assembling machines, increasing the responsibility of the tasks they solve, the problem of ensuring reliability becomes urgent. A successful solution to this problem depends on the quality of organizational, technical, information and methodological support (Fig. 1) [6].

\begin{tabular}{|c|c|}
$\begin{array}{c}\text { Principles of ensuring the reliability of } \\
\text { complex technical systems }\end{array}$ \\
\hline$\rightarrow$ Organizational support \\
\hline & Technical support \\
& Information support \\
& Methodological support
\end{tabular}

Fig. 1. Principles of ensuring the reliability of complex technical systems

Organizational support covers the planning and implementation of works on reliability parameters, organization of relevant services, economic and legal and administrative relations between the customer, the developer and the manufacturer.
Technical support is characterized by the industry equipment with PC (personal electronic computers), applied software, experimental and production facilities, the level of technology and metrology.

Information support is the means and ways of collecting, accumulating, processing and using data on the processes of system development and operation, the results of the analysis of failures and defects. In addition, data on changes in documentation, violation of production stability, failure to meet deadlines and other factors of deviation from the planned development and application of technology are analyzed.

Methodological support includes the theoretical basis and engineering methods for analyzing the reliability of systems at various stages of the life cycle of the machine, as well as the methods and algorithms used in the implementation and analysis of the results of the implementation of reliability programs.

Ensuring reliability, as one of the main tasks of the development and application of complex technical systems, is realized within the organizational structure of engineering. Therefore, one of the areas to ensure reliability, in particular responsible parts of the drilling tool and its technological equipment, is to improve the organizational structure itself, as well as in the development and implementation of additional activities. These measures will stimulate the provision of reliability and the level of the parameters of the organizational structure.

\section{The object of research and its technological audit}

The object of research is a finishing-strengthening technological operation and implementing its safety systems to provide indicators of reliability of drilling pump bushings.

Technical and economic indicators of drilling operations depend on the effectiveness of drilling tools. However, the durability of the drilling tool, in particular the roller type, depends to a large extent on the timely injection of drilling fluid (water, clay) into the well during geological 
exploration and structural search drilling for oil and gas. This is provided by drilling pumps (НБ32, НБ50, etc.) [7]. To the loaded parts of the pump, in particular НБ32, include the details of the hydraulic part: pistons, cylindrical bushings, piston and slider rods, valves and valve seats. Providing reliability and increasing the life of critical parts of pumps, in particular cylinder bushings, with technological methods will increase the competitiveness and efficiency of drilling equipment.

The modern technology of manufacturing any parts puts high demands both on the productivity of the equipment used and on the accuracy and quality of the surfaces being treated [1]. At the same time, experience in the operation of machines, instruments, apparatus convincingly demonstrates that reliability and durability depend on the nature of the contact of the conjugate parts with each other or with liquid, gas and other media. This determines the state of the surface layer of the contact parts $[1,2,5]$. In addition, numerous studies have established that the quality of the surface of machine parts significantly determines the wear resistance, strength, corrosion resistance and other operational properties of machine parts.

The formation of quality parameters, performance characteristics and reliability indicators occurs at the finishing and finishing-strengthening operations of technological processes of manufacturing products. The methods of mechanical processing, realizing finishing technological operations, which allow to control the quality of the surface layer only within narrow limits, while the reserves of strength of materials remain unused [1]. To implement finishing-strengthening operations of technological processes apply chemical-thermal methods of processing and coating and pressure treatment (surface plastic deformation). When using chemical-thermal methods of processing and coating, it is necessary to employ highly skilled workers to service specific equipment. And the widespread industrial use of chemicalthermal methods is hampered by the extremely high energy intensity of the process.

An effective technological method for the implementation of finishing-strengthening operations of technological processes to ensure the reliability of engineering products is surface hardening by means of various methods of surface plastic deformation, in particular using vibrations.

For technological support of surface quality indicators of machine parts and mechanisms, a method of vibrationcentrifugal reinforcement has been developed [1, 2]. The most common in the engineering practice of technological equipment and accessories for vibration-centrifugal devices with unbalanced and electromagnetic drive has its advantages and disadvantages, limiting the scope of their use. Not always effective were attempts to adapt vibrating machines of volumetric processing for vibration-centrifugal strengthening of products.

Therefore, the problem of reliability of modern machine building products, in particular cylinder bushings of drilling pumps, penetrating in the production and operation of machines, requires a systematic approach to making technological decisions. And also requires the development of new and improvement of existing technological processes for the manufacture of products $[1,2,6,8]$.

\section{The aim and objectives of research}

The aim of research is analysis of the influence of vibration-centrifugal reinforcement method and the technological equipment that implements it on the reliability indices of cylinder bushings of drilling pumps on the finishingstrengthening operation of the manufacturing process.

To achieve this aim, it is necessary to solve the following tasks:

1. To adapt the method of volumetric vibration processing for vibration-centrifugal reinforcement of internal surfaces of cylindrical bores of НБ32 drilling pump and design technological equipment for its implementation.

2. To experimentally investigate and conduct full-scale tests on the influence of vibration-centrifugal reinforcement on the parameters of failure-free cylinder liners.

\section{Research of existing solutions of the problem}

A feature of the reliability problem is its relationship with all stages of the life cycle of the machine (Fig. 2), starting with the stage of formation and substantiation of the idea of its creation, and ending with the decision to write-off (recycling) the product or mechanism. When calculating and designing, the reliability parameters are laid in the design, while manufacturing - are provided, during operation- are implemented [8-12].
The life cycle of the machine

\begin{tabular}{|c|c|}
\hline \multicolumn{2}{|c|}{ Machine creation stage } \\
\hline \begin{tabular}{c|c} 
Stage of design and technological \\
preparation of production
\end{tabular} \\
\hline $\begin{array}{c}\text { Design } \\
\text { preparation } \\
\text { of production }\end{array}$ & $\begin{array}{c}\text { Technological } \\
\text { preparation } \\
\text { of production }\end{array}$ \\
\hline
\end{tabular}

Fig. 2. The life cycle of the machine

At present, fundamental results have been obtained in reliability theory in two main areas of research: probabilistic-statistical (for technical systems with complex structure and complex connections between elements) and deterministic, connected with the study of failure physics. Within the framework of the first direction, mathematical methods for estimating reliability, statistical processing of test and operation results, developing highly reliable structures of technical systems, planning tests, monitoring and prediction of reliability have been developed. Within the framework of the second direction, the mechanisms of the processes that have the main influence on reliability are studied, methods for calculating strength and wear are developed, new technological methods for increasing the reliability of materials, elements and objects in general are developed. Currently, there is a process of merging these two directions, with methods and results from one area being used in another, and on this basis a common general science is emerging about the reliability of technical objects [8-12].

The modern theory of reliability is based on the fundamental laws of mathematics and natural sciences [8, 9, 13-16]. Operational reliability and efficiency of machinery 
and equipment of drilling complexes are considered to be the basic criteria ensuring the profitability of modern drilling production [7].

The technological process of drilling is carried out in close interrelation of all complexes of equipment of various functional purposes, in which failure or malfunction of one node or element leads to failure of the system object or the whole complex as a whole. In this case, interruptions in the drilling process are often accompanied by the occurrence of accidents that hamper the technological organization of emergency liquidation works [7].

The technological process of manufacturing, assembling and controlling the product should ensure the necessary level of product quality and reliability indicators with minimal time and money [1, 2, 17-23]. However, these two sides often contradict: the increase in productivity is accompanied by a decrease in quality, and, conversely, high quality is achieved at lower productivity. However, the reliability characteristics that appear during the operation of the products are often ignored (Fig. 2, 3), although it is the reliability and durability that provide the desired service life of machine parts, in particular oil and gas equipment [1, 2, 7].

Directly establish the relationship between the starting, current and output parameters of the technological process and the reliability indicators are super complicated (Fig. 3) [8, 9]. Reliability indicators are associated with the operational properties of products - wear resistance, corrosion resistance, fatigue strength, heat resistance, etc., and process parameters with processing accuracy and surface topography microrelief characteristics. Therefore, in practice, as a rule, the main parameters of surface quality are analyzed and investigated in correlation with the operational properties of machines and devices, which they determine $[1-3,5,8,14]$.

In relation to engineering products, in particular drilling tool parts, the potential reliability that is achieved in the course of its development and design, and the actual reliability that is provided in the manufacturing process, depending on the design and technological preparation of production, are distinguished [7].

The potential reliability of an object $P_{0}$ determines its maximum achievable reliability [7]:

$$
P_{O}=P_{\text {str }} \cdot P_{\text {elem }} \cdot P_{\text {prod }}
$$

where $P_{\text {str }}, P_{\text {elem }}, P_{\text {prod }}$ - potential, respectively, reliability of the design, components and production processes.

Potential reliability of the structure. $P_{s t r}$ is defined as the probability that the technical requirements of the drilling equipment specified in the regulatory documentation remain within the specified parameters unless a sudden failure occurs.

Potential reliability of elements $P_{\text {elem }}$ is defined as the probability that the elements will operate normally for a certain time under specified power conditions and operating conditions:

$$
P_{\text {elem }}=k_{i} \cdot k_{c} \cdot k_{e}
$$

where $k_{i}$ - coefficient that takes into account the failure rate of elements of a given type for a certain period of time; $k_{c}$ - coefficient that takes into account operational conditions (temperature, humidity, etc.); $k_{e}$ - coefficient characterizing the type of equipment (power, lifting, etc.).

Potential reliability of production processes $P_{\text {prod }}$ is defined as the probability that individual technological operations are completed without allowable defects.

In real operational conditions, the gap between potential and practical reliability is appreciably given the hidden and obvious defects (40-85\% of the total). These defects are laid down at the stage of creating the machine (Fig. 3), which cause failure during the operation stage $[7,8,14]$.

It is usually difficult for a technologist to provide a substantiated rationale for an activity related to improving the reliability of a product, since its results are manifested only after a long period of time and not in the sphere of activity of the enterprise. At the same time, the entire organization of the production of this product, the used technological processes and the methods of control have a decisive influence on reliability indicators. It has been established [1, 2, 9, 17-23] that the finishing and finishingstrengthening operations of the technological process have a direct and significant effect on reliability indicators, although these relationships are complex and multi-stage, and not obvious. One of the main components of reliability is failure-free operation - the ability of the product to continuously maintain its performance for a certain period or operating time, the main parameters of which are relative to the bores of drilling pumps [6, 7]:

- probability of failure-free operation (reliability factor) $P(t)$;

- average time between failures $T_{a v}$;

- average time between failures $T_{0}$

- failure flow parameter $\omega(t)$

- failure rate $\lambda(t)$

- probability of failure of a certain type $q_{0}$.

The reliability problem in modern machine building is complex. It penetrates into the sphere of production and operation of machines, various fields of knowledge are involved in its solution, it requires the adoption of new organizational and technical solutions [8].

Therefore, the use of theoretical and practical bases of the reliability theory to increase the life of details such as the «cylinder», «cylinder» of oil and gas production equipment and the implementation of effective finishing and finishing-strengthening operations of technological processes for their manufacture will help develop efficient

\begin{tabular}{|c|c|c|c|}
\hline $\begin{array}{l}\text { The technological } \\
\text { process (sequence } \\
\text { of operations, } \\
\text { processing modes, } \\
\text { etc.) }\end{array}$ & $\begin{array}{l}\text { Parameters of } \\
\text { product quality } \\
\text { (accuracy of } \\
\text { processing, surface } \\
\text { quality, etc.) }\end{array}$ & $\begin{array}{l}\text { Parameters of } \\
\text { product quality } \\
\text { (accuracy of } \\
\text { processing, surface } \\
\text { quality, etc.) }\end{array}$ & $\begin{array}{l}\text { Reliability } \\
\text { indicators } \\
\text { (reliability factor, } \\
\text { resource, etc.) }\end{array}$ \\
\hline
\end{tabular}
designs of drilling equipment.

Fig. 3. The scheme of dependence of reliability indicators on the level of the technological process [8] 


\section{Methods of research}

5.1. Materials and experimental samples. Considering that most of the «cylinder», «bushing» parts of the oil and gas production equipment are made of structural steels, experimental samples of bushings made of two materials were used for experimental studies:

- steel 70 GOST 1050-88 (according to specifications);

- steel 20 (as an alternative).

The prototype drawings are shown in Fig. 4.

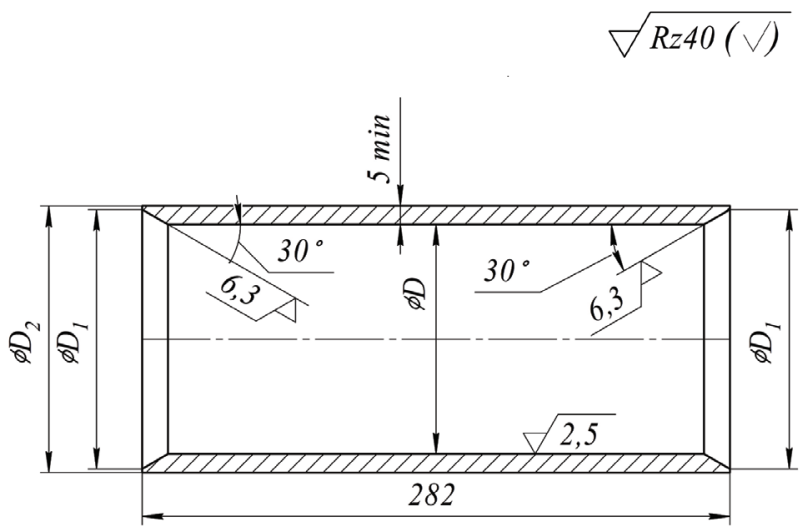

\begin{tabular}{|c|c|c|c|}
\hline Dignations & $\mathrm{D}, \mathrm{mm}$ & $\mathrm{D}_{1}, \mathrm{~mm}$ & $\mathrm{D}_{2 \text { min }}, \mathrm{mm}$ \\
\hline НБ 32.02.102-02 & $100^{+0,4}$ & 110 & 110 \\
\hline HБ 32.02.102-02 & $110^{+0,4}$ & 120 & 120 \\
\hline
\end{tabular}

Fig. 4. Drawings of the prototype

5.2. Technological equipment for the implementation of vibration-centrifugal hardening of «bushing» parts. Technological capabilities, scope and classification features of the method of vibration-centrifugal hardening of machine parts such as «bushing» are described in [2].

The universality of vibration-centrifugal reinforcement makes it possible to use other vibration-centrifugal reinforcement methods for its implementation. At the «Lviv Polytechnic» National University (Ukraine), the first attempts were made to adapt the volumetric vibration processing equipment for vibration-centrifugal reinforcement of the inner surfaces of cylindrical products, in particular cylinder bores of the drilling pump НБ32. In addition, the technological equipment for its implementation has been designed. Technological equipment (Fig. 5) consists of a collector whose outer surface is strengthened with polyurethane, lids and coniferous joints, by means of which the cutter is installed in the hole of the part and the volume between them is filled with deformed bodies (balls).

Fig. 6 is a schematic diagram of a vibration-centrifugal strengthening device with an unbalanced cause for processing the inner surface of «bushing» type parts. Rotational motion is transmitted to the bodies of the exciter 6 from the electric motors 3 through the couplings 5 . The shafts of both electric motors 3 rotate synchronously and in phase in one direction. From mechanical damages and external influences, the exciter is protected by enclosures 8 .

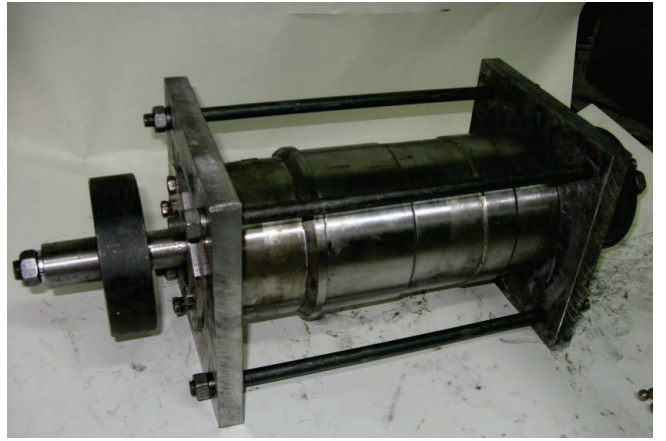

$a$

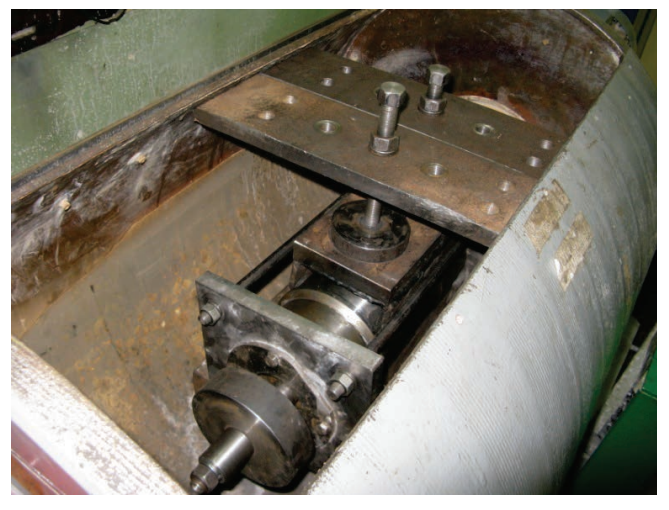

Fig. 5. Technological equipment for vibration-centrifugal reinforcement of the internal surfaces of cylindrical products on the vibrator of volumetric processing: a - technological equipment with bushing assembly; $b$ - technological equipment in vibration machine with bushing assembly
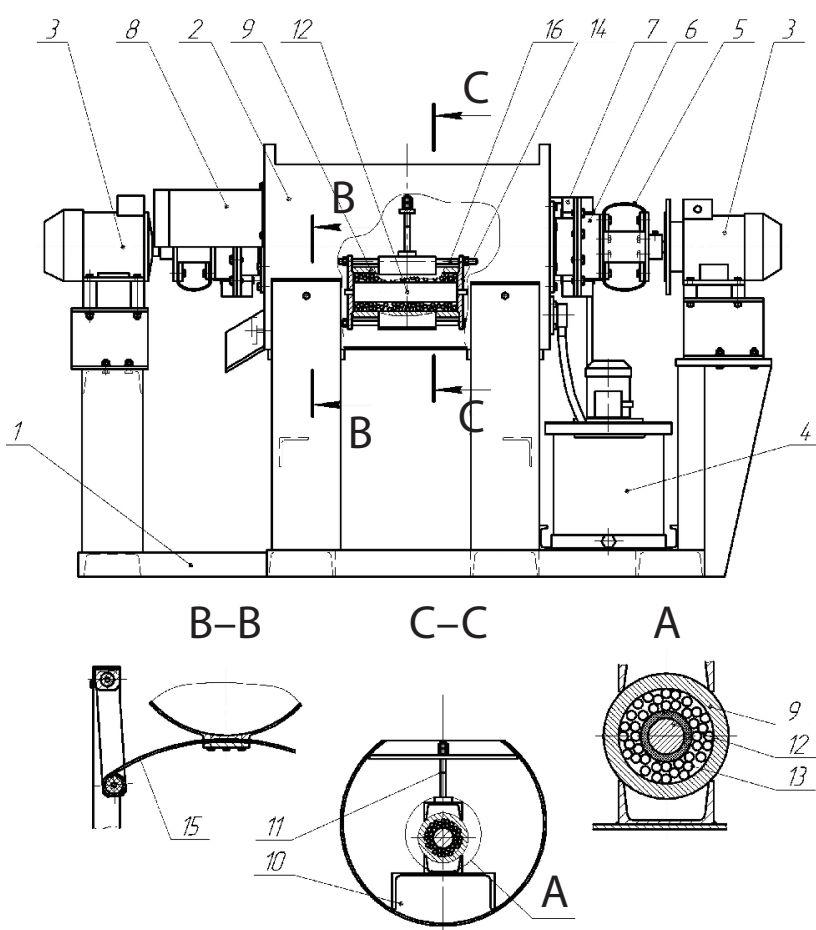

Fig. 6. Schematic diagram of the unbalanced strengthening device

The finishing-strengthening treatment of the inner surfaces of the bushings is carried out in this sequence. When voltage is applied to the windings of the motors 3 , 
rotational motion of the unbalance vibration exciter 7 is provided. The rotation of the unbalances causes the plane-parallel vibrations of the workpiece 9 to be excited with given amplitude in a plane perpendicular to its geometric axis.

Due to the oscillations of the workpiece, the roller 12 installed in it self-extends into a vibration-supporting rotational mode, which is accompanied by embossing along the inner machined surface of the long-length cylindrical workpiece 9 .

The finishing-strengthening treatment of the inner surfaces of the bushing is carried out in this sequence. When voltage is applied to the windings of the motors 3 , a rotational movement of the unbalance 7 of the vibration exciter 6 is provided. The rotation of the unbalances 7 causes the plane-parallel vibrations of the workpiece 9 to be excited with predetermined amplitude in a plane perpendicular to its geometric axis. Due to the oscillations of the workpiece, the roller12 installed in it selfextends into a vibration-supporting rotational mode, which is accompanied by coiling along the inner machined surface of the cylindrical bushing of the drilling pump 9 .

The engraving of the roller 12 takes place along the deformable bodies placed between it and the workpiece 13. A discrete time interval for contacting the inner surface of the workpiece 9 with the roller 12 occurs through a small number of balls 13 arranged along the generatrix of the workpiece surface. The contact of the part with the next group of balls occurs with impact, and the bodies collide, there are massive roller 12 and workpiece 9 .

The presence of the workpiece spinwood with the roller when contacting them through a small number of deformable elements leads to the development of large contact stresses in the material of the workpiece at the points of contact, as a result of which the processed material is plastically deformed and strengthened.

The thickness of the strengthened layer, the degree and uniformity of the reinforcement is regulated by changing the treatment time, the standard sizes of the deformed bodies, the mass of the collector, the amplitude of the oscillations.

Strengthening the coater with polyurethane instead of rubber significantly increases the tool life. To process a cylindrical sleeve of a different size $\left(100^{+0.14} \mathrm{~mm}, 110^{+0.14} \mathrm{~mm}, 120^{+0.14} \mathrm{~mm}\right.$, etc. $)$, another roller is manufactured and strengthened with polyurethane.

5.3. Method of implementation of experimental studies. Experimental studies were carried out on a volumetric vibrating machine. The initial roughness of the surface of the prototype obtained after turning has been determined to carry out the tests.

Before the treatment of the deformed body, it was wetted with water to reduce friction and improve the condition of the wrapping. After unit, the assembly was assembled from the workpiece, the deformable bodies and the roller, and then fixed to the unit. The time of vibration-centrifugal treatment of the prototype is $15 \mathrm{~min}$. After processing, the bushings were sent to full-scale tests.

\section{Research results}

6.1. Results of full-scale tests of drilling pump bushings. Vibration-centrifugal-strengthened bushings of drilling pumps made of steel 20 and original bushings of steel 70 in pairs were installed on drilling pumps. During full-scale tests, the bushing operating time were fixed to failure, the results are given in Table 1 . The test report is shown in Fig. 7.

Table 1

Results of full-scale tests of drilling pump bushings

\begin{tabular}{|l|l|l|l|l|l|l|l|l|l|l|}
\hline $\begin{array}{l}\text { Operating time of the } \\
\text { base bushing, } T_{i}\end{array}$ & 420 & 405 & 417 & 410 & 391 & 415 & 382 & 389 & 408 & 417 \\
\hline $\begin{array}{l}\text { Operating time of the } \\
\text { vibration-strengthened } \\
\text { bushing, } T_{i}\end{array}$ & 752 & 643 & 683 & 708 & 630 & 638 & 609 & 651 & 674 & 706 \\
\hline
\end{tabular}

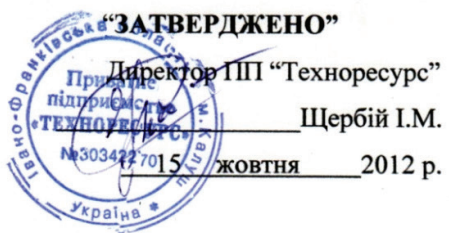

AKT

про результати випробувань

втулок циліндрових бурових насосів НБ-32

Ми, що нижче підписалися, представник ПП "Техноресурс" - головний технолог Федишин В.М. та представник Калуської НГРЄ ДП «Укрзахідгеологія» головний механік Гоц В.П., склали цей акт про результати випробувань циліндрових втулок бурових насосів НБ-32:

було проведено дослідно-промислові випробування циліндрових втулок бурових насосів НБ-32, виготовлених із сталі 20 ГОСТ 1050-74. На оздоблювально-викінчувальній технологічній операції при виготовленні циліндрових втулок бурових насосів НБ-32 здійснено вібраційно-відцентрове зміцнення у Національному університеті «Львівська політехніка» на кафедрі «Технологія машинобудування».

Застосування вібраційно-відцентрового зміцнення у ТП виготовлення циліндрових втулок бурових насосів НБ-32 дозволило при збереженні вимог нормативної документації забезпечити експлуатаційний ресурс не менший, ніж у базових втулок, виготовлених із сталі 70 ГОСТ 1050-74, зокрема, під час проведених випробувань ресурс базових втулок із сталі 70 - 420 год, віброзміцнених втулок із сталі 20 - 752 год. Крім цього, використання віброційно-відцентрового зміцнення сприяло зменшенню загальної працемісткості механічного оброблення та собівартості виготовлення виробу.

Акт складений у трьох примірниках.

Головний технолог ППП "Техноресурс"

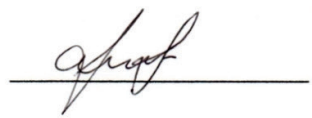

Федишин В.М.

Головний механік

Калуської НГР€

ДП "Укрзахідгеологія"

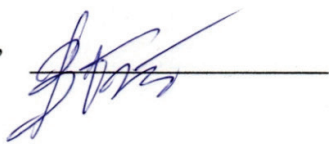

Гоц В.П.

Fig. 7. Certificate of test results for cylinder bushings 
6.2. Determination of the main parameters of the failurefree operation of products. To determine the basic indicators of product reliability, let's construct a graph (Fig. 8), dividing the operating time into intervals by the boundaries $t_{2}=200 \mathrm{~h}, t_{3}=300 \mathrm{~h}, t_{4}=400 \mathrm{~h}, t_{5}=500 \mathrm{~h}, t_{6}=600 \mathrm{~h}$, $t_{7}=700 \mathrm{~h}, t_{8}=800 \mathrm{~h}$

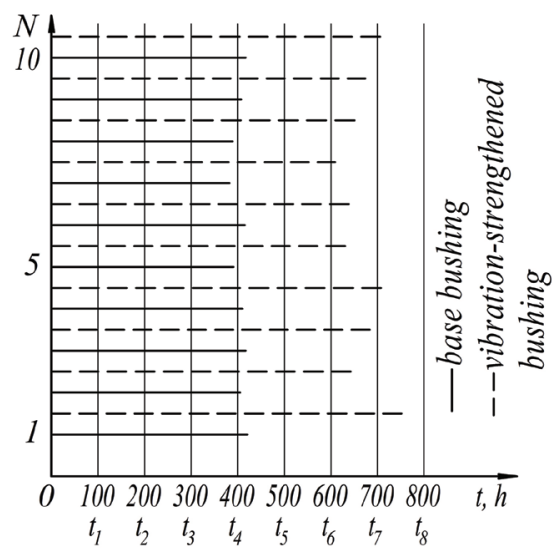

Fig 8. Results of full-scale tests of bushings

6.2.1. Probability of failure-free operation (reliability factor) $\hat{P}\left(t_{i}\right)$. The probability of failure-free operation $\widehat{P}\left(t_{i}\right)$ is determined by the formula:

$$
\widehat{P}\left(t_{i}\right)=\widehat{P}\left(0, t_{i}\right)=\frac{N_{t_{i}}}{N},
$$

where $N_{t_{i}}$ - the number of products, finalized until the end of the specified interval; $N$ - the total number of products.

For base bushing:

$$
\begin{aligned}
& \hat{P}\left(t_{1}\right)=\widehat{P}\left(0, t_{1}\right)=\frac{N_{t_{1}}}{N}=\frac{10}{10}=1.0 ; \\
& \hat{P}\left(t_{2}\right)=\widehat{P}\left(0, t_{2}\right)=\frac{N_{t_{2}}}{N}=\frac{10}{10}=1.0 ; \\
& \hat{P}\left(t_{3}\right)=\widehat{P}\left(0, t_{3}\right)=\frac{N_{t_{3}}}{N}=\frac{10}{10}=1.0 ; \\
& \hat{P}\left(t_{4}\right)=\hat{P}\left(0, t_{4}\right)=\frac{N_{t_{4}}}{N}=\frac{7}{10}=0.7 ; \\
& \hat{P}\left(t_{5}\right)=\widehat{P}\left(0, t_{5}\right)=\frac{N_{t_{5}}}{N}=\frac{0}{10}=0 ; \\
& \hat{P}\left(t_{6}\right)=\widehat{P}\left(0, t_{6}\right)=\frac{N_{t_{6}}}{N}=\frac{0}{10}=0 ; \\
& \hat{P}\left(t_{7}\right)=\widehat{P}\left(0, t_{7}\right)=\frac{N_{t_{7}}}{N}=\frac{0}{10}=0 ; \\
& \hat{P}\left(t_{8}\right)=\widehat{P}\left(0, t_{8}\right)=\frac{N_{t_{8}}}{N}=\frac{0}{10}=0 .
\end{aligned}
$$

For vibration-strengthened bushing:

$$
\begin{aligned}
& \widehat{P}\left(t_{1}\right)=\widehat{P}\left(0, t_{1}\right)=\frac{N_{t_{1}}}{N}=\frac{10}{10}=1.0 ; \\
& \widehat{P}\left(t_{2}\right)=\widehat{P}\left(0, t_{2}\right)=\frac{N_{t_{2}}}{N}=\frac{10}{10}=1.0 ;
\end{aligned}
$$

$$
\begin{aligned}
& \widehat{P}\left(t_{3}\right)=\widehat{P}\left(0, t_{3}\right)=\frac{N_{t_{3}}}{N}=\frac{10}{10}=1.0 ; \\
& \widehat{P}\left(t_{4}\right)=\widehat{P}\left(0, t_{4}\right)=\frac{N_{t_{4}}}{N}=\frac{10}{10}=1.0 ; \\
& \widehat{P}\left(t_{5}\right)=\widehat{P}\left(0, t_{5}\right)=\frac{N_{t_{5}}}{N}=\frac{10}{10}=1.0 ; \\
& \widehat{P}\left(t_{6}\right)=\widehat{P}\left(0, t_{6}\right)=\frac{N_{t_{6}}}{N}=\frac{10}{10}=1.0 ; \\
& \widehat{P}\left(t_{7}\right)=\widehat{P}\left(0, t_{7}\right)=\frac{N_{t_{7}}}{N}=\frac{3}{10}=0.3 ; \\
& \widehat{P}\left(t_{8}\right)=\widehat{P}\left(0, t_{8}\right)=\frac{N_{t_{8}}}{N}=\frac{0}{10}=0 .
\end{aligned}
$$

A histogram of the reliability function for the base and strengthened bushes is shown in Fig. 9.

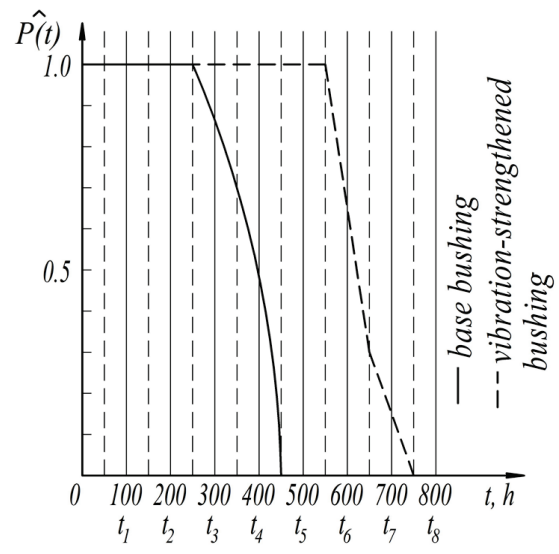

Fig. 9. Reliability function histogram

The conditional probability is determined by the formula:

$$
P\left(t_{k}, t_{i}\right)=\frac{P\left(t_{i}\right)}{P\left(t_{k}\right)} .
$$

For base bushing:

$$
\begin{aligned}
& P\left(0, t_{1}\right)=\frac{P\left(0, t_{1}\right)}{P(0)}=\frac{N\left(t_{1}\right)}{N(0)}=\frac{10}{10}=1.0 ; \\
& P\left(t_{1}, t_{2}\right)=\frac{P\left(0, t_{2}\right)}{P\left(0, t_{1}\right)}=\frac{N\left(t_{2}\right)}{N\left(t_{1}\right)}=\frac{10}{10}=1.0 ; \\
& P\left(t_{2}, t_{3}\right)=\frac{P\left(0, t_{3}\right)}{P\left(0, t_{2}\right)}=\frac{N\left(t_{3}\right)}{N\left(t_{2}\right)}=\frac{10}{10}=1.0 ; \\
& P\left(t_{3}, t_{4}\right)=\frac{P\left(0, t_{4}\right)}{P\left(0, t_{3}\right)}=\frac{N\left(t_{4}\right)}{N\left(t_{3}\right)}=\frac{7}{10}=0.7 ; \\
& P\left(t_{4}, t_{5}\right)=\frac{P\left(0, t_{5}\right)}{P\left(0, t_{4}\right)}=\frac{N\left(t_{5}\right)}{N\left(t_{4}\right)}=\frac{0}{7}=0 ; \\
& P\left(t_{5}, t_{6}\right)=\frac{P\left(0, t_{6}\right)}{P\left(0, t_{5}\right)}=\frac{N\left(t_{6}\right)}{N\left(t_{5}\right)}=\frac{0}{0}=0 ;
\end{aligned}
$$




$$
\begin{aligned}
& P\left(t_{6}, t_{7}\right)=\frac{P\left(0, t_{7}\right)}{P\left(0, t_{6}\right)}=\frac{N\left(t_{7}\right)}{N\left(t_{6}\right)}=\frac{0}{0}=0 ; \\
& P\left(t_{7}, t_{8}\right)=\frac{P\left(0, t_{8}\right)}{P\left(0, t_{7}\right)}=\frac{N\left(t_{8}\right)}{N\left(t_{7}\right)}=\frac{0}{0}=0 .
\end{aligned}
$$

For vibration-strengthened bushing:

$$
\begin{aligned}
& P\left(0, t_{1}\right)=\frac{P\left(0, t_{1}\right)}{P(0)}=\frac{N\left(t_{1}\right)}{N(0)}=\frac{10}{10}=1.0 ; \\
& P\left(t_{1}, t_{2}\right)=\frac{P\left(0, t_{2}\right)}{P\left(0, t_{1}\right)}=\frac{N\left(t_{2}\right)}{N\left(t_{1}\right)}=\frac{10}{10}=1.0 ; \\
& P\left(t_{2}, t_{3}\right)=\frac{P\left(0, t_{3}\right)}{P\left(0, t_{2}\right)}=\frac{N\left(t_{3}\right)}{N\left(t_{2}\right)}=\frac{10}{10}=1.0 ; \\
& P\left(t_{3}, t_{4}\right)=\frac{P\left(0, t_{4}\right)}{P\left(0, t_{3}\right)}=\frac{N\left(t_{4}\right)}{N\left(t_{3}\right)}=\frac{10}{10}=1.0 ; \\
& P\left(t_{4}, t_{5}\right)=\frac{P\left(0, t_{5}\right)}{P\left(0, t_{4}\right)}=\frac{N\left(t_{5}\right)}{N\left(t_{4}\right)}=\frac{10}{10}=1.0 ; \\
& P\left(t_{5}, t_{6}\right)=\frac{P\left(0, t_{6}\right)}{P\left(0, t_{5}\right)}=\frac{N\left(t_{6}\right)}{N\left(t_{5}\right)}=\frac{10}{10}=1.0 ; \\
& P\left(t_{6}, t_{7}\right)=\frac{P\left(0, t_{7}\right)}{P\left(0, t_{6}\right)}=\frac{N\left(t_{7}\right)}{N\left(t_{6}\right)}=\frac{3}{10}=0.3 ; \\
& P\left(t_{7}, t_{8}\right)=\frac{P\left(0, t_{8}\right)}{P\left(0, t_{7}\right)}=\frac{N\left(t_{8}\right)}{N\left(t_{7}\right)}=\frac{0}{3}=0 .
\end{aligned}
$$

6.2.2. Failure rate $\lambda(t)$. The failure rate is estimated by the formula:

$$
\lambda\left(t_{i}, t_{i+1}\right)=\frac{\Delta Q_{i+1}}{\Delta t}=\frac{\Delta n_{i+1}}{N_{t_{i}} \cdot \Delta t},
$$

where $\Delta n_{i+1}$ - the number of failures at a given interval; $N_{t_{i}}-$ number of products, finalized until the end of the previous interval, $\Delta t$ - time interval, h.

For base bushing:

$$
\begin{aligned}
& \lambda\left(0, t_{1}\right) \approx \lambda\left(t_{1}\right)=\frac{0}{(10-0) \cdot(100-0)}=0 ; \\
& \lambda\left(t_{1}, t_{2}\right) \approx \lambda\left(t_{2}\right)=\frac{0}{(10-0) \cdot(200-100)}=0 ; \\
& \lambda\left(t_{2}, t_{3}\right) \approx \lambda\left(t_{3}\right)=\frac{0}{(10-0) \cdot(300-200)}=0 ; \\
& \lambda\left(t_{3}, t_{4}\right) \approx \lambda\left(t_{4}\right)=\frac{3}{(10-0) \cdot(400-300)}=0.0031 / \mathrm{h} ; \\
& \lambda\left(t_{4}, t_{5}\right) \approx \lambda\left(t_{5}\right)=\frac{7}{(10-3) \cdot(500-400)}=0.011 / \mathrm{h} .
\end{aligned}
$$

For vibration-strengthened bushing:

$$
\lambda\left(0, t_{1}\right) \approx \lambda\left(t_{1}\right)=\frac{0}{(10-0) \cdot(100-0)}=0 ;
$$

$$
\begin{aligned}
& \lambda\left(t_{1}, t_{2}\right) \approx \lambda\left(t_{2}\right)=\frac{0}{(10-0) \cdot(200-100)}=0 ; \\
& \lambda\left(t_{2}, t_{3}\right) \approx \lambda\left(t_{3}\right)=\frac{0}{(10-0) \cdot(300-200)}=0 ; \\
& \lambda\left(t_{3}, t_{4}\right) \approx \lambda\left(t_{4}\right)=\frac{0}{(10-0) \cdot(400-300)}=0 ; \\
& \lambda\left(t_{4}, t_{5}\right) \approx \lambda\left(t_{5}\right)=\frac{0}{(10-0) \cdot(500-400)}=0 ; \\
& \lambda\left(t_{5}, t_{6}\right) \approx \lambda\left(t_{6}\right)=\frac{0}{(10-0) \cdot(600-500)}=0 ; \\
& \lambda\left(t_{6}, t_{7}\right) \approx \lambda\left(t_{7}\right)=\frac{7}{(10-0) \cdot(700-600)}=0.0071 / \mathrm{h} ; \\
& \lambda\left(t_{7}, t_{8}\right) \approx \lambda\left(t_{8}\right)=\frac{3}{(10-7) \cdot(800-700)}=0.011 / \mathrm{h} .
\end{aligned}
$$

6.2.3. Average operating time of the bushing to failure $T_{a v}$. The average operating time of the bushing $T_{a v}$ to failure is determined by the formula:

$$
T_{a v}=\frac{\sum_{i=1}^{N_{f}} t_{i}+N_{f f} \cdot T_{t}}{N},
$$

where $N_{f}$ - the number of items that failed during the test; $t_{i}$ - the operating time of each failed product; $N_{f f}$ - number of products, worked without fail during the test time, $T_{t}-$ test duration (or total operating time).

To determine the test time $T_{a v}$, let's assume the same for the base bushing $T_{t}=420 \mathrm{~h}$, for the strengthened $T_{t}=752 \mathrm{~h}$.

For base bushing:

$$
\begin{aligned}
& T_{a v}=(405+417+410+391+415+382+389+408+ \\
& +417+1 \cdot 420): 10=405.4 \mathrm{~h} .
\end{aligned}
$$

For vibration-strengthened bushing:

$$
\begin{aligned}
& T_{a v}=(643+683+708+630+638+609+651+ \\
& +674+706+1 \cdot 752): 10=669.4 \mathrm{~h} .
\end{aligned}
$$

Based on the certificate of the results of full-scale testing of cylinder bushings of drilling pumps НБ32 (Fig. 9) and determination of their main parameters of non-failure operation, the following conclusions can be drawn. After the vibration-centrifugal reinforcement of the cylinder bushings of the drilling pumps, the dynamics of the change in the reliability factor, conditional probability and the failure rate for vibration-strengthened bushings is better than for base bushings manufactured according to the standard process. The average time between failures $T_{a v}$ for vibrationstrengthened bushings increased by 1.65 times compared with the base bushes. In addition, a change in material from steel 70 to steel 20 for vibration-strengthened bushings will also provide a component of the economic effect.

\section{SWOT analysis of research results}

Strengths. Advantages of the this method consist in providing a high level of deformation energy, high productivity, 
simplicity, reliability, compactness and versatility of the strengthening devices, the possibility of qualitative processing of the internal surfaces of the parts of the shape of the bodies of revolution. The process of vibration-centrifugal reinforcement does not change the geometric shape of the part, does not require special allowance for processing, and can be used to strengthen products from both nonferrous metals and alloys and from various steel grades. Especially effective vibration-centrifugal reinforcement is for the machining of parts subjected to alternating cyclic loads and various types of wear, in particular responsible parts of the drilling tool, during the operation [1, 2].

Weaknesses. Despite the advantages of the method of vibration-centrifugal reinforcement, in order to develop practical recommendations for the introduction of the method into the practice of modern engineering, it is necessary to conduct a considerable number of experimental and field tests for a particular class of products and their specified sizes.

Opportunities. Further studies in this direction are aimed at selecting rational processing regimes and developing practical recommendations on the use of vibration-centrifugal reinforcements with an unbalanced cause for improving the performance characteristics of bushing-type parts and predicting the parameters of their reliability.

When introducing this invention into production, it is possible to switch to cheaper materials when manufacturing cylindrical bushings of drilling pumps and taking into account the increased resource, use less raw material for their manufacture.

Threats. When implementing this product, the enterprise must additionally spend money on designing and manufacturing vibration machines, mastering the technology of vibration-centrifugal reinforcement and training of personnel.

\section{Conclusions}

1. The method of volumetric vibration processing for vibration-centrifugal reinforcement of inner surfaces of cylindrical bushings of НБ32 drilling pump with the use of previously manufactured vibration equipment has been adapted. The technological equipment for its realization has been designed. For experimental studies, the material of the bushings made of steel 70 on steel 20 has been changed and their internal execution surfaces have been strengthened using vibrations.

2. In-situ tests on the influence of vibration-centrifugal reinforcement on the reliability parameters of cylindrical bushings are experimentally investigated and conducted $s$. Average time between failures $T_{a v}$ of vibration-strengthened bushings increased by 1.65 times compared with the base bushings. In addition, a change in material from steel 70 to steel 20 for vibration-strengthened bushings will also provide a component of the economic effect.

\section{References}

1. Kusyj J. M. Tekhnolohichne zabezpechennia fizyko-mekhanichnykh parametriv poverkhnevykh shariv metalevykh dovhomirnykh tsylindrychnykh detalei vibratsiino-vidtsentrovym zmitsnenniam: abstract's PhD thesis. Lviv, 2002. 260 p.

2. Kusyj J., Kuk A. Method devised to improve technological reliability of machine parts // Eastern-European Journal of Enterprise Technologies. 2015. Vol. 1, No. 7 (73). P. 41-51. doi:10.15587/1729-4061.2015.36336
3. Kusyj J., Kuzin O., Kuzin N. The dependence of intergrain damageability of casting on the technological treatment route // Eastern-European Journal of Enterprise Technologies. 2016. Vol. 1, No. 5 (79). P. 39-47. doi:10.15587/1729-4061.2016.59845

4. Kuzin O., Kusyj J., Topilnytskyj V. Influence of technological heredity on reliability parameters of products // Technology Audit and Production Reserves. 2015. Vol. 1, No. 1 (21). P. 15-21. doi:10.15587/2312-8372.2015.37678

5. Suslov A. G. Kachestvo poverkhnostnogo sloya detaley mashin. Moscow: Mashinostroenie, 2000. 320 p.

6. Aleksandrovskaya L. N., Afanasiev A. P., Lisov A. A. Sovremennye metody obespecheniya bezotkaznosti slozhnykh tekhnicheskikh sistem: handbook. Moscow: Logos, 2001. 208 p.

7. Bykov I. Yu., Tskhadaya N. D. Ekspluatatsionnaya nadezhnost' i rabotosposobnost' burovykh mashin: handbook. Ukhta: UGTU, 2004. 196 p.

8. Pronikov A. S. Nadezhnost' mashin. Moscow: Mashinostroenie, 1978. 592 p.

9. Dalskiy A. M. Tekhnologicheskoe obespechenie nadezhnosti vysokotochnykh detaley mashin. Moscow: Mashinostroenie, 1975. 319 p.

10. Skoogh A., Perera T., Johansson B. Input data management in simulation - Industrial practices and future trends // Simulation Modelling Practice and Theory. 2012. Vol. 29. P. 181-192. doi:10.1016/j.simpat.2012.07.009

11. Wang L. Data representation of machine models. Dynamic thermal analysis of machines in running state. London: SpringerVerlag, 2014. P. 11-29. doi:10.1007/978-1-4471-5273-6_2

12. McDowell D. L. Simulation-assisted materials design for the concurrent design of materials and products // Journal of the Minerals. Metals and Materials Society. 2007. Vol. 59, No. 9. P. 21-25. doi:10.1007/s11837-007-0111-7

13. Durham S. D., Padgett W. I. Cumulative damage models for system failure with application to carbon fibers and composites // Technometrics. 1997. Vol. 39, No. 1. P. 34-44. doi:10.2307/1270770

14. McEvily A. J. Metal Failures: Mechanisms, Analysis, Prevention. John Wiley \& Sons, 2013. 480 p. doi:10.1002/9781118671023

15. Zohdi T. I., Wriggers P. An introduction to computational micromechanics // Lecture Notes in Applied and Computational Mechanics. Springer, 2005. 198 p. doi:10.1007/978-3540-32360-0

16. Kundu T. Fundamentals of fracture mechanics. Boca Raton: CRC Press, 2008. 304 p.

17. Yashheritsyn P. I., Ryzhov E. V., Averchenko V. I. Tekhnologicheskaya nasledstvennost' v mashinostroenii. Minsk: Nauka i tekhnika, 1977. 256 p.

18. Aftanaziv I., Kusyj J., Kuritnyk I.-P. Using vibrations for strengthening of long-sized cylindrical details // Acta Mechanica Slovaca. Kosice. 2000. Vol. 3. P. 43-46.

19. Stotsko Z., Kusyj J., Topilnytskyj V. Research of vibratorycentrifugal strain hardening on surface quality of cylindric long-sized machine parts // Journal of Manufacturing and Industrial Engineering. 2012. Vol. 11, No. 1. P. 15-17.

20. Aftanaziv I. S. Reliability technological providing of machines details. Lviv: DULP, 1998. 132 p.

21. Jashcheritcyn P. I., Minakov A. P. The non-rigid details strengthening's treatment in the engineer. Minsk: Nauka i tekhnika, 1986. 215 p.

22. Schneider Y. G. Operating properties of details with regular microrelief. Leningrad: Mashinostroenie. Leningradskoe otdelenie, 1982. 248 p.

23. Tehnologicheskie osnovy upravleniia kachestvom mashin / Vasiliev A. S. et al. Moscow: Mashinostroenie, 2003. 256 p. 


\section{ВЛИЯНИЕ ВИБРАЦИОННО-ЦЕНТРОБЕЖНОГО УПРОЧНЕНИЯ}

\section{НА ПАРАМЕТРЫ БЕЗОТКАЗНОСТИ ВТУЛОК БУРОВЫХ НАСОСОВ}

Проанализированы причины отказов деталей бурового оборудования. Разработан метод вибрационно-центробежного упрочнения для обеспечения показателей надежности деталей типа «втулка». Адаптирована вибромашина объемной обработки для поверхностного вибрационно-центробежного упрочнения. Приведена принципиальная схема вибромашины и технологическая оснастка для упрочнения втулок. Обработаны и проанализированы результаты экспериментальных исследований и натурных испытаний.

Ключевые слова: технологическая оснастка для упрочнения втулок, буровой инструмент, цилиндровая втулка, вибрационноцентробежное укрепление.
Kusyj Jaroslav, PhD, Associate Professor, Department of Mechanical Engineering Technology, Lviv Polytechnic National University, Ukraine, e-mail: jarkym@ukr.net, ORCID: http://orcid.org/ 0000-0001-5741-486X

Kuk Andrij, PhD, Associate Professor, Department of Mechanical Engineering Technology, Lviv Polytechnic National University, Ukraine, e-mail: andrij.kuk@gmail.com, ORCID: http://orcid.org/0000-00019145-243X

Topilnytskyy Volodymyr, PhD, Associate Professor, Department of Designing and Operation of Machines, Lviv Polytechnic National University, Ukraine, e-mail: topilnvol@gmail.com, ORCID: http:// orcid.org/0000-0002-5191-326X 